\title{
Frequencies of polymorphisms in genes affecting the pharmacokinetics of warfarin in the Zaporizhzhia region
}

\author{
M. Yu. Kolesnyk (1),E,F, Ya. M. Mykhailovskyi (iD*B,C,D
}

Zaporizhzhia State Medical University, Ukraine

A - research concept and design; B - collection and/or assembly of data; C - data analysis and interpretation; D - writing the article;

$\mathrm{E}$ - critical revision of the article; $\mathrm{F}$ - final approval of the article

Key words: warfarin, pharmacogenetics, genes, prevalence.

Zaporozhye

medical journal

2021; 23 (4), 476-479

*E-mail:

yarikzgmu@gmail.com
The aim of the study: to establish the frequencies of polymorphisms in VKORC1, CYP2C9 and CYP4F2 genes among residents of the Zaporizhzhia region.

Materials and methods. A total of 150 persons ( 62 male, 88 female) with a median age of 46 years $(26 ; 58)$ undergoing preventive examination at the Medical Educational and Scientific Center "University Clinic" of Zaporizhzhia State Medical University (ZSMU). The CYP2C9, CYP4F2, VKORC1 genes polymorphisms in atrial fibrillation patients were determined in the Department of Molecular Genetic Studies of the ZSMU Medical Laboratory Center. Amplification of DNA fragments containing polymorphic regions was performed using multiplex real time polymerase chain reaction with Warfarin Pharmacogenetics kits (LLC NPO DNA Technology) in a CFX-96 thermocycler (BioRad) with a fluorescence detection scheme.

Results. It was determined that among Zaporizhzhia region residents, the frequencies of CYP2C9*2 genotypes were: C/C $77.3 \%, \mathrm{C} / \mathrm{T}-22.7 \%$, T/T - 0; CYP2C9*3 genotypes: A/A - 88.7\%, A/C - $10.7 \%$, C/C - 0.6 \%; CYP4F2 genotypes: $\mathrm{C} / \mathrm{C}-56.0 \%, \mathrm{C} / \mathrm{T}-35.3 \%$, T/T $-8.7 \%$; VKORC1 genotypes: G/G - 38.0 \%, G/A - $50.0 \%$, A/A - $12.0 \%$. There were no statistically significant differences in the distribution of genotype frequencies between males and females and between different age groups. The frequencies of CYP2C9, CYP4F2, VKORC1 genotypes in different populations were compared. Their variability in different geographic regions was established.

Conclusions. CYP4F2 and VKORC1 genes polymorphisms are more common in the Zaporizhzhia region, while the prevalence of CYP2C9*2 and CYP2C9*3 genes polymorphisms is much lower. It is necessary to take into account the prevalence of genes polymorphisms that affect warfarin metabolism for each individual population to select its dose by pharmacogenetic testing.
Ключові слова: варфарин, фармакогенетика, гени, поширеність.

\section{Запорізький} медичний журнал 2021. T. 23, № 4(127). C. $476-479$

\section{Поширеність поліморфізмів генів, що впиивають на фармакокінетику варфарину, серед жителів Запорізького регіону}

\section{М. Ю. Колесник, Я.М.Михайловський}

Мета роботи - встановити частоту поширення поліморфізмів генів, що впливають на фрармакокінетику варфарину (ВФ), серед жителів Запорізького регіону.

Матеріали та методи. Обстежили 150 осіб віком 46 (26; 58) років (62 чоловіки, 88 жінок), які проходили просрілактичний огляд у Діагностичному центрі «Здоров'я» на базі ННМЦ «Університетська клініка» Запорізького державного медичного університету. Поліморфізми генів CYP2C9, CYP4F2, VKORC1 досліджували методом полімеразної ланцюгової реакції в режимі реального часу у відділі молекулярно-генетичних досліджень навчального медико-лабораторного центру ЗДМУ. Ампліфікацію фрагментів ДНК, що містять поліморфні ділянки, виконали за допомогою полімеразної ланцюгової реакції наборами SNP-експрес-фрармакогенетика (TOB «НПО ДНК-Технологія») в ампліфікаторі CFX-96 (BioRad) із фрлуоресцентною схемою детекції.

Результати. Встановили, що в жителів Запорізької області частота виявлення генотипів за поліморфним варіантом гена CYP2C9*2 становить: C/C - 77,3 \%, C/T - 22,7 \%, Т/T - не виявлено; гена CYP2C9*3: A/A - 88,7 \%, A/C - 10,7\%, C/C - 0,6 \%; гена CYP4F2: C/C - 56,0 \%, C/T - 35,3\%, T/T - 8,7\%; гена VKORC1: G/G - 38,0 \%, G/A - 50,0\%, A/A - 12,0\%. Статистично вірогідних відмінностей за розподілом частот генотипів між чоловіками та жінками, групами осіб різних вікових груп не виявили. Зіставили частоту реєстрації поліморфних варіантів генів CYP2C9, CYP4F2, VKORC1 у популяціях, встановили їхню варіабельність у різних географічних регіонах.

Висновки. У Запорізькому регіоні більш поширені поліморфізми генів CYP4F2 i VKORC1, поширеність поліморфізмів генів CYP2C9*2 та CYP2C9*3 суттєво менша. Застосовуючи фрармакогенетичне тестування для визначення дози варфарину, потрібно враховувати поширеність поліморфізму генів, що впливають на його метаболізм, для кожної окремої популяції.

Ключевые слова: варфарин, фармакогенетика, гены, распространённость.

\section{Запорожский} медицинский журнал. 2021. T. 23, № 4(127) C. $476-479$

\section{Распространённость полиморфизмов генов, вяияющих на фармакокинетику варфарина, среди жителей Запорожского региона}

\section{М. Ю. Колесник, Я. М. Михайловский}

Цель работы - установить частоту распространения полиморфизмов генов, влияющих на фрармакокинетику варфарина (ВФ), среди жителей Запорожского региона.

Материалы и методы. Обследовали 150 человек в возрасте 46 (26; 58) лет (62 мужчины, 88 женщин), которые проходили профрилактический осмотр в Диагностическом центре «Здоровье» на базе ННМЦ «Университетская клиника» Запорожского 
государственного медицинского университета. Полиморфизмы генов CYP2C9, CYP4F2, VKORC1 исследовали методом полимеразной цепной реакции в режиме реального времени в отделе молекулярно-генетических исследований учебного медико-лабораторного центра ЗГМУ. Амплификация фрагментов ДНК, содержащих полиморфные участки, проведена с помощью полимеразной цепной реакции наборами SNP экспресс-фармакогенетика (ООО «НПО ДНК-Технология») в амплификаторе CFX-96 (BioRad) с фрлуоресцентной схемой детекции.

Результаты. Установлено, что у жителей Запорожской области частота выявления генотипов по полиморфному варианту гена CYP2C9*2 составляет: С/C -77,3\%, C/T -22,7 \%, Т/T - не обнаружен; гена CYP2C9*3: A/A - 88,7 \%, A/C - 10,7 \%, C/C - 0,6 \%; гена CYP4F2: C/C - 56,0 \%, C/T - 35,3\%, T/T - 8,7\%; гена VKORC1: G/G - 38,0 \%, G/A - 50,0 \%, A/A $12,0 \%$. Статистически достоверные различия по распределению частот генотипов между мужчинами и женщинами, разными возрастными группами не установлены. Сопоставили частоту регистрации полиморфных вариантов генов СҮР2C9, CYP4F2, VKORC1 в популяциях, установили их вариабельность в различных географических регионах.

Выводы. В Запорожском регионе более распространены полиморфизмы генов CYP4F2 и VKORC1, распространённость полиморфизмов генов CYP2C9*2 и СYР2C9³ значительно меньше. При использовании фармакогенетического тестирования для определения дозы варфарина нужно учитывать распространённость полиморфизма генов, влияющих на его метаболизм, для каждой отдельной популяции.

The global aspect that determines the safety of drug interventions, minimizing the occurrence of side effects, are the genetic characteristics of a patient, especially the polymorphism in genes involved in drug metabolism. Therefore, today a new area of personalized medicine is pharmacogenetics, which allows to optimize pharmacotherapy for individual patients [1,2]. In real clinical practice, pharmacogenetic testing is recommended for long-term use of drugs with a narrow therapeutic range, variable pharmacokinetics and a significant severity of side effects [2-4].

Such drugs include warfarin (WF) - an oral anticoagulant used to prevent thromboembolism in patients with atrial fibrillation (AF) $[3,5,6]$. Today, a whole range of genes that affect WF metabolism and cause different sensitivity to the drug is known. The largest contribution to WF dose variability make polymorphisms in the cytochrome P450 2C9 gene (CYP2C9), the vitamin K epoxide reductase complex subunit 1 gene (VKORC1) and the gene encoding an enzyme that is thought to inactivate vitamin K (CYP4F2) [7,8]. In this regard, the scientific literature describes algorithms for calculating the initial dose of WF based on the results of pharmacogenetic testing [9]. It is necessary to emphasize that genetic testing in practical medicine should take into account the population characteristics of the selected genetic variants prevalence, as well as their contribution to the dosage and the development of side effects in a particular population. [2]. In the Zaporizhzhia region, the prevalence of polymorphisms of the VKORC1, CYP2C9 and CYP4F2 genes was not studied.

\section{Aim}

To establish the frequencies of polymorphisms in VKORC1, CYP2C9 and CYP4F2 genes among residents of the Zaporizhzhia region.

\section{Materials and methods}

A total of 150 persons ( 62 male, 88 female) with a median age of 46 years $(26 ; 58)$ undergoing preventive examination at the Medical Educational and Scientific Center "University Clinic" of Zaporizhzhia State Medical University (ZSMU).

All persons gave their informed consent to participate.
CYP2C9, CYP4F2, VKORC1 genes polymorphisms were determined in the Department of Molecular Genetic Research of the Training Medical and Laboratory Center of ZSMU (director - Prof. A. V. Abramov). Peripheral blood samples were obtained from each participant and transferred to ethylenediamine tetraacetic acid (EDTA) containing tubes in order to prevent clotting. DNA samples were extracted from whole blood leukocytes using a set of reagents TEST-RAPID-GENETICS ("DNA-Technology"). Amplification of DNA fragments containing polymorphic regions was performed using a real-time polymerase chain reaction with Warfarin Pharmacogenetics kits ("DNA Technology") in a CFX-96 thermocycler (BioRad) with a fluorescent detection scheme. $20 \mu$ of pre-centrifuged suitable mixture for amplification were added to the test tubes. A 20:1 mixture of PCR buffer with Taq-AT polymerase was prepared separately and centrifuged for $1-3$ seconds. $10 \mu \mathrm{l}$ of a mixture of PCR buffer with Taq-AT polymerase were added to the test tubes with the amplification mixture. 1 drop of mineral oil was added to each test tube. $5 \mu$ of DNA was added to the appropriate tubes with aerosol barrier tips. The same manipulations were performed with the control sample. After centrifugation for 1-3 seconds, amplification was performed. PCR results were recorded automatically by software.

The principles of bioethics were observed in the study: the basic provisions of the European Council Convention on Human Rights and Biomedicine (dated 04.04.1997), GCP (1996), the World Medical Association's Helsinki Declaration

Table 1. Comparison of the CYP2C9, CYP4F2 and VKORC1 genotypes frequencies with calculated frequencies according to the Hardy-Weinberg equilibrium (HWE)

\begin{tabular}{|c|c|c|c|c|c|}
\hline \multirow{2}{*}{\multicolumn{2}{|c|}{ Genotypes }} & Cases & HWE & \multirow{2}{*}{$x^{2}$} & \multirow[t]{2}{*}{$\mathbf{P}$} \\
\hline & & $n=150$ & $n=150$ & & \\
\hline \multirow[t]{3}{*}{ CYP2C9*1 } & $\mathrm{C} / \mathrm{C}$ & $116 / 0.773$ & $118 / 0.786$ & \multirow[t]{3}{*}{2.45} & \multirow[t]{3}{*}{0.29} \\
\hline & $\mathrm{C} / \mathrm{T}$ & $34 / 0.227$ & $30 / 0.201$ & & \\
\hline & $\mathrm{T} / \mathrm{T}$ & $0 / 0$ & $2 / 0.013$ & & \\
\hline \multirow[t]{3}{*}{ CYP2C9*2 } & $\mathrm{A} / \mathrm{A}$ & $133 / 0.887$ & $133 / 0.884$ & \multirow[t]{3}{*}{0.44} & \multirow[t]{3}{*}{0.80} \\
\hline & $\mathrm{A} / \mathrm{C}$ & $16 / 0.107$ & $16 / 0.112$ & & \\
\hline & $\mathrm{C} / \mathrm{C}$ & $1 / 0.006$ & $1 / 0.004$ & & \\
\hline \multirow[t]{3}{*}{ CYP4F2 } & $\mathrm{C} / \mathrm{C}$ & $84 / 0.560$ & $81 / 0.543$ & \multirow[t]{3}{*}{1.20} & \multirow[t]{3}{*}{0.55} \\
\hline & $\mathrm{C} / \mathrm{T}$ & $53 / 0.353$ & $58 / 0.388$ & & \\
\hline & $\mathrm{T} / \mathrm{T}$ & $13 / 0.087$ & $10 / 0.069$ & & \\
\hline \multirow[t]{3}{*}{ VKORC1 } & $\mathrm{G} / \mathrm{G}$ & $57 / 0.380$ & $60 / 0.397$ & \multirow[t]{3}{*}{0.79} & \multirow[t]{3}{*}{0.67} \\
\hline & $\mathrm{G} / \mathrm{A}$ & $75 / 0.500$ & $70 / 0.467$ & & \\
\hline & $\mathrm{A} / \mathrm{A}$ & $18 / 0.120$ & $20 / 0.137$ & & \\
\hline
\end{tabular}


Table 2. The prevalence of the CYP2C9 alleles among different ethnic groups

\begin{tabular}{|c|c|c|c|c|}
\hline Polymorphism & Region & \multicolumn{2}{|c|}{ Allele frequency } & P-value \\
\hline \multirow[t]{9}{*}{$\mathrm{C} / \mathrm{T}$} & Our study & $C=0.887$ & $T=0.113$ & - \\
\hline & Ukraine [10] & $C=0.915$ & $\mathrm{~T}=0.085$ & $P>0.05$ \\
\hline & America [11] & $C=0.992$ & $T=0.008$ & $P<0.05$ \\
\hline & East Asia [11] & $C=0.998$ & $T=0.002$ & $P<0.05$ \\
\hline & South Asia [11] & $C=0.929$ & $T=0.071$ & $P>0.05$ \\
\hline & Europe [11] & $C=0.873$ & $T=0.127$ & $P>0.05$ \\
\hline & Central Asia [11] & $C=0.840$ & $T=0.160$ & $P<0.05$ \\
\hline & Oceania [11] & $C=1.000$ & $T=0$ & $P<0.05$ \\
\hline & Africa [11] & $C=0.995$ & $T=0.005$ & $P<0.05$ \\
\hline \multirow[t]{9}{*}{$\mathrm{A} / \mathrm{C}$} & Our study & $A=0.931$ & $C=0.069$ & - \\
\hline & Ukraine [10] & $A=0.925$ & $C=0.074$ & $P>0.05$ \\
\hline & America [11] & $A=0.984$ & $C=0.016$ & $P>0.05$ \\
\hline & East Asia [11] & $A=0.957$ & $C=0.043$ & $P>0.05$ \\
\hline & South Asia [11] & $A=0.899$ & $C=0.101$ & $P>0.05$ \\
\hline & Europe [11] & $A=0.914$ & $C=0.086$ & $P>0.05$ \\
\hline & Central Asia [11] & $A=0.933$ & $C=0.067$ & $P>0.05$ \\
\hline & Oceania [11] & $A=0.953$ & $C=0.065$ & $P>0.05$ \\
\hline & Africa [11] & $A=1.000$ & $C=0$ & $P<0.05$ \\
\hline
\end{tabular}

Table 3. The prevalence of VKORC1 gene polymorphism among different ethnic groups

\begin{tabular}{|c|c|c|c|c|}
\hline \multirow{2}{*}{$\begin{array}{l}\text { Polymorphism } \\
\text { G/A }\end{array}$} & \multirow{2}{*}{$\begin{array}{l}\text { Region } \\
\text { Our study }\end{array}$} & \multicolumn{2}{|c|}{ Allele frequency } & \multirow{2}{*}{$\begin{array}{l}\text { P-value } \\
-\end{array}$} \\
\hline & & $G=0.630$ & $A=0.370$ & \\
\hline & Ukraine [12] & $G=0.610$ & $A=0.390$ & $P>0.05$ \\
\hline & African Americans [13] & $G=0.900$ & $A=0.100$ & $P<0.05$ \\
\hline & Europe [14] & $G=0.578$ & $A=0.422$ & $P>0.05$ \\
\hline & Latin America [15] & $G=0.670$ & $A=0.330$ & $P>0.05$ \\
\hline & Japane [16] & $G=0.080$ & $A=0.920$ & $P<0.05$ \\
\hline & Egypt [17] & $G=0.555$ & $A=0.445$ & $P>0.05$ \\
\hline & India [18] & $G=0.908$ & $A=0.092$ & $P<0.05$ \\
\hline
\end{tabular}

Table 4. The prevalence of CYP4F2 gene polymorphism among different ethnic groups

\begin{tabular}{|c|c|c|c|c|}
\hline Polymorphism & Region & \multicolumn{2}{|c|}{ Allele frequency } & P-value \\
\hline \multirow{9}{*}{$\mathrm{C} / \mathrm{T}$} & Our study & $C=0.737$ & $T=0.263$ & - \\
\hline & Worlwide [19] & $C=0.763$ & $T=0.237$ & $P>0.05$ \\
\hline & America [19] & $C=0.762$ & $T=0.268$ & $P>0.05$ \\
\hline & East asia [11] & $C=0.708$ & $T=0.292$ & $P>0.05$ \\
\hline & South Asia [19] & $C=0.587$ & $\mathrm{~T}=0.413$ & $P>0.05$ \\
\hline & Europe [19] & $C=0.710$ & $T=0.290$ & $P>0.05$ \\
\hline & Central Asia [11] & $C=0.597$ & $T=0.403$ & $P<0.05$ \\
\hline & Oceania [11] & $C=0.387$ & $T=0.613$ & $P<0.05$ \\
\hline & Africa [11] & $C=0.930$ & $\mathrm{~T}=0.070$ & $P<0.05$ \\
\hline
\end{tabular}

on Ethical principles of bioethics, Principles for Scientific and Human Research (1964-2000) and the Order of the Ministry of Health of Ukraine No. 281 of 01.11.2000.

Statistical data processing was performed using the program Statistica 13.0 for Windows (StatSoft Inc., license No. JPZ8041382130ARCN10-J). Comparison of qualitative indicators and assessment of the genotype distributions conformity to the expected Hardy-Weinberg equilibrium values were performed using the Yates-adjusted criterion $X^{2}$. The differences were considered significant at $P<0.05$.

\section{Results}

According to the results of the CYP2C9*2 gene polymorphism genotyping, wild allele (genotype $\mathrm{C} / \mathrm{C}$ ) homozygotes were found in $116(77.3 \%)$ cases, heterozygotes (C/T) -in $34(22.7 \%)$, mutant allele (T/T) homozygotes were not observed. The $\mathrm{C}$ allele frequency was $88.7 \%$, T allele $11.3 \%$. In the study of the CYP2C9*3 gene polymorphism, wild allele (A/A) homozygotes were found in $133(88.7 \%)$ cases, heterozygotes $(\mathrm{A} / \mathrm{C})$ - in $16(10.7 \%)$, mutant allele $(\mathrm{C} / \mathrm{C})$ homozygotes - in $1(0.6 \%)$ case. The A allele frequency was $94.0 \%$, C allele $-6.0 \%$.

The most common CYP4F2 genotype was $\mathrm{C} / \mathrm{C}-84$ (56.0\%) cases. There were $53(35.3 \%)$ and $13(8.7 \%)$ subjects carrying the $\mathrm{C} / \mathrm{T}$ or T/T genotype in the CYP4F2 gene, respectively. The $\mathrm{C}$ allele frequency was $73.7 \%$, allele T-26.3\%.

According to the VKORC1 genotyping results, 57 (38.0\%) persons had the G/G genotype, 75 (50.0\%) A/A genotype, $18(12.0 \%)-A / A$ genotype. The $G$ allele frequency was $63.0 \%$, A allele $-37.0 \%$.

As shown in Tables 1, 2, 3, 4, no significant deviations from the Hardy-Weinberg equilibrium were observed.

There were no statistically significant differences in the distribution of genotype frequencies between males and females and between different age groups.

\section{Discussion}

We compared the obtained genotype frequencies with the all-Ukrainian population and other ethnic groups studied by a number of authors. The prevalence of the CYP2C9 gene polymorphisms is shown in Table 2.

As can be seen from the table, the prevalence of CYP2C9 C/T gene polymorphism was the same in Zaporizhzhia, all-Ukrainian population, Europe and South Asia. At the same time, the $\mathrm{C}$ allele was more common in America, East Asia, Oceania, and Africa compared with our study, and the T allele was more common in Central Asia. The $\mathrm{A} / \mathrm{C}$ polymorphism did not show a significant difference in allele frequencies between different geographical regions, except Africa, where the $\mathrm{C}$ allele did not occur.

The prevalence of VKORC1 gene polymorphisms among different ethnic groups is shown in Table 3.

The $G$ and $A$ alleles of the VKORC1 gene prevalence varies in different geographical regions. Thus, the mutant $A$ allele dominates in Japanese, is less common in Egyptians, Ukrainians (in our study and in the general population), Europeans and Latinos, is very rare in African Americans and is almost non-existent in Indians.

The prevalence of CYP4F2 gene polymorphism is shown in Table 4.

The frequency of polymorphic alleles of the CYP4F2 gene is comparable in our study, Europe, East and South Asia. The $\mathrm{C}$ allele is more common in America and Africa, and the T allele is more common in Central Asia and Oceania than in the Zaporizhzhia region.

\section{Conclusions}

1. The frequency of genes polymorphisms that affect the pharmacokinetics of warfarin varies in different geo- 
graphical regions, which determines the feasibility of study on the genotypes distribution for each population.

2.CYP4F2andVKORC1 genetic polymorphismsaremore common in the Zaporizhzhia region, while the prevalence of CYP2C9*2 and CYP2C9*3 genetic polymorphisms is much lower.

Prospects for further research. Due to the widespread prevalence of genetic polymorphisms affecting WF pharmacokinetics, further research will focus on comparing the efficacy and safety of traditional and pharmacogenetic approaches to WF dosing.

\section{Funding}

The study was performed within the interdepartmental scientific research of Zaporizhzhia State Medical University “Comorbid conditions, cardiovascular and oncological diseases in general clinical practice: development of modern diagnostic and therapeutic agents", state registration No. 0120 U101587.

Conflicts of interest: authors have no conflict of interest to declare. Конфлікт інтересів: віАсутній.

Надійшла до редакції / Received: 16.03.2021

Після Аоопрацювання / Revised: 15.04.2021

Прийнято Ао Аруку / Accepted: 23.04.2021

Information about the authors:

Kolesnyk M. Yu., MD, PhD, DSc, Professor of the Department of Family Medicine, Therapy, Cardiology and Neurology of Faculty of Postgraduate Education, Zaporizhzhia State Medical University, Ukraine.

ORCID ID: 0000-0001-7566-1899

Mykhailovskyi Ya. M., MD, PhD-student of the Department of Family Medicine, Therapy, Cardiology and Neurology of Faculty of Postgraduate Education, Zaporizhzhia State Medical University, Ukraine.

ORCID ID: 0000-0002-1310-8585

\section{Відомості про авторів:}

Колесник М. Ю., А-р меА. наук, професор каф. сімейної медицини, терапії, кардіології та неврології факультету післяАипломної освіти, Запорізький Аержавний меАичний університет, Україна.

Михайловський Я. М., PhD-аспірант каф. сімейної медицини, терапії, кардіології та неврології факультету післядипломної освіти, Запорізький державний медичний університет, Україна.

\section{Сведения об авторах:}

Колесник М. Ю., А-р меА. наук, профессор каф. семейной медицины, терапии, карАиологии и неврологии факультета послеАипломного образования, Запорожский государственный меАицинский университет, Украина.

Михайловский Я. M., PhD-аспирант каф. семейной меАицины, терапии, карАиологии и неврологии факультета послеАипломного образования, Запорожский государственный медицинский университет, Украина.

\section{References}

[1] Abdullah-Koolmees, H., van Keulen, A. M., Nijenhuis, M., \& Deneer, V. (2021). Pharmacogenetics Guidelines: Overview and Comparison of the DPWG, CPIC, CPNDS, and RNPGx Guidelines. Frontiers in Pharmacology, 11, Article 595219. https://doi.org/10.3389/fphar.2020.595219

[2] Francis Lam, Y. W., \& Scott, Stuart A. (Eds.). (2019). Pharmacogenomics. Challenges and Opportunities in Therapeutic Implementation (2nd ed.). Academic Press. https://doi.org/10.1016/C2016-0-03878-0

[3] Picard, N., Boyer, J. C., Etienne-Grimaldi, M. C., Barin-Le Guellec, C., Thomas, F., Loriot, M. A., \& French National Network of Pharmacogenetics (RNPGX). (2017). Pharmacogenetics-based personalized therapy: Levels of evidence and recommendations from the French Network of Pharmacogenetics (RNPGx). Therapie, 72(2), 185-192. https://doi.org/10.1016/i.therap.2016.09.014

[4] Sychev, D. A. (2011). Rekomendatsii po primeneniyu farmakogeneticheskogo testirovaniya $v$ klinicheskoi praktike [Recommendations for the use of pharmacogenetic testing in clinical practice]. Kachestvennaya Klinicheskaya Praktika, (1), 3-10. https://www.clinvest.ru/jour/article/ view/135?locale=ru RU [in Russian].

[5] Graham, D. J., Baro, E., Zhang, R., Liao, J., Wernecke, M., Reichman, M. E., Hu, M., Illoh, O., Wei, Y., Goulding, M. R., Chillarige, Y. Southworth, M. R., MaCurdy, T. E., \& Kelman, J. A. (2019). Comparative Stroke, Bleeding, and Mortality Risks in Older Medicare Patients Treated with Oral Anticoagulants for Nonvalvular Atrial Fibrillation. The American Journal of Medicine, 132(5), 596-604.e11. https://doi. org/10.1016/j.amjmed.2018.12.023

[6] Johnson, J. A., Caudle, K. E., Gong, L., Whirl-Carrillo, M., Stein, C. M. Scott, S. A., Lee, M. T., Gage, B. F., Kimmel, S. E., Perera, M. A., Anderson, J. L., Pirmohamed, M., Klein, T. E., Limdi, N. A., Cavallari, L. H., \& Wadelius, M. (2017). Clinical Pharmacogenetics Implementation Consortium (CPIC) Guideline for Pharmacogenetics-Guided Warfarin Dosing: 2017 Update. Clinical Pharmacology \& Therapeutics, 102(3), 397-404. https://doi.org/10.1002/cpt.668

[7] Sridharan, K., \& Sivaramakrishnan, G. (2021). A network meta-analysis of CYP2C9, CYP2C9 with VKORC1 and CYP2C9 with VKORC1 and CYP4F2 genotype-based warfarin dosing strategies compared to traditional. Journal of Clinical Pharmacy and Therapeutics, 46(3), 640-648. https://doi.org/10.1111/jcpt.13334

[8] Sun, X., Yu, W. Y., Ma, W. L., Huang, L. H., \& Yang, G. P. (2016). Impact of the CYP4F2 gene polymorphisms on the warfarin maintenance dose: Asystematic review and meta-analysis. Biomedical Reports, 4(4), 498506. https://doi.org/10.3892/br.2016.599

[9] Asiimwe, I. G., Zhang, E. J., Osanlou, R., Jorgensen, A. L., \& Pirmohamed, M. (2021). Warfarin dosing algorithms: A systematic review. British Journal of Clinical Pharmacology, 87(4), 1717-1729. https://doi. org/10.1111/bcp. 14608

[10] Levkovich, N. M., \& Gorovenko, N. G. (2013) Chastota rozpovsiudzhennia alelnykh variantiv * $2 \mathrm{i}$ * 3 hena CYP2C 9 u naselennia Ukrainy [Allele frequency distribution of CYP2C9 gene in Ukrainian population] Odeskyi medychnyi zhurnal, (2), 23-28. [in Ukrainian].

[11] Ross, K. A., Bigham, A. W., Edwards, M., Gozdzik, A., Suarez-Kurtz, G. \& Parra, E. J. (2010). Worldwide allele frequency distribution of four polymorphisms associated with warfarin dose requirements. Journal of Human Genetics, 55(9), 582-589. https://doi.org/10.1038/ihg.2010.73

[12] Maliarchuk, I. V., Gorovenko, N. G., Krykunov, A. O., \& Babochkina, A. R. (2014). Klinichne znachennia polimorfnoho varianta G1639A hena VKORC1 $\mathrm{v}$ indyvidualizatsii terapii varfarynom [The clinical significance of G1639A polymorphic variants of VKORC1 gene for individualized therapy with warfarin]. Ukrainskyi kardiolohichnyi zhurnal, (2), 100-105. [in Ukrainian].

[13] Ohara, M., Suzuki, Y., Shinohara, S., Gong, I. Y., Schmerk, C. L., Tirona, R. G., Schwarz, U. I., Wen, M. S., Lee, M., Mihara, K., Nutescu, E. A., Perera, M. A., Cavallari, L. H., Kim, R. B., \& Takahashi, H. (2019). Differences in Warfarin Pharmacodynamics and Predictors of Response Among Three Racial Populations. Clinical Pharmacokinetics, 58(8), 1077-1089. https://doi.org/10.1007/s40262-019-00745-5

[14] Buzoianu, A. D., Trifa, A. P., Mureşanu, D. F., \& Crişan, S. (2012). Analysis of CYP2C9*2, CYP2C9*3 and VKORC1 -1639 G>A polymorphisms in a population from South-Eastern Europe. Journal of Cellular and Molecular Medicine, 16(12), 2919-2924. https://doi.org/10.1111/i.15824934.2012.01606.x

[15] Cavallari, L. H., Momary, K. M., Patel, S. R., Shapiro, N. L., Nutescu, E. \& Viana, M. A. (2011). Pharmacogenomics of warfarin dose requirements in Hispanics. Blood Cells, Molecules, and Diseases, 46(2), 147-150. https://doi.org/10.1016/i.bcmd.2010.11.005

[16] Kimura, R., Miyashita, K., Kokubo, Y., Akaiwa, Y., Otsubo, R., Nagatsuka, K., Otsuki, T., Okayama, A., Minematsu, K., Naritomi, H., Honda, S., Tomoike, H., \& Miyata, T. (2007). Genotypes of vitamin K epoxide reductase, gamma-glutamyl carboxylase, and cytochrome P450 2C9 as determinants of daily warfarin dose in Japanese patients. Thrombosis Research, 120(2), 181-186. https://doi.org/10.1016/j.thromres.2006.09.007

[17] Bedewy, A., Sheweita, S. A., Mostafa, M. H., \& Kandil, L. S. (2018). The Influence of CYP2C9 and VKORC1 Gene Polymorphisms on the Response to Warfarin in Egyptians. Indian Journal of Hematology and Blood Transfusion, 34(2), 328-336. https://doi.org/10.1007/s12288-016-0725-4

[18] Harikrishnan, S., Koshy, L., Subramanian, R., Sanjay, G., Vineeth, C. P., Nair, A. J., Nair, G. M., \& Sudhakaran, P. R. (2018). Value of VKORC1 $(-1639 \mathrm{G}>A)$ rs9923231 genotyping in predicting warfarin dose: A replication study in South Indian population. Indian Heart Journal, 70(Suppl. 3), S110-S115. https://doi.org/10.1016/j.ihj.2018.07.006

[19] EMBL-EBI. (n.d.). rs2108622. SNP. Ensembl.org. http://www.ensembl, org/Homo sapiens/Variation/Population?db=core $;=19: 15879121-158$ $\underline{\text { 80121; v=rs2108622; vdb=variation; } v f=202396216}$ 